\title{
Necrotizing leukoencephalitis in a Yorkshire dog from Brazil
}

\section{Leucoencefalite necrosante em um cão Yorkshire do Brasil}

\author{
Alexandre Mendes Amude ${ }^{1 *}$; Mônica Vicky Bahr Arias²; Selwyn Arlington \\ Headley $^{3}$; Ana Paula Frederico Rodrigues Loureiro Bracarense ${ }^{3}$; \\ Natalino Francisco Silva ${ }^{4}$; Amauri Alcindo Alfieri ${ }^{5}$
}

\begin{abstract}
Necrotizing leukoencephalitis (NLE) is an uncommon inflammatory condition of brain of dogs, and was described in dogs from North America, Europe, and Asia. Cases of NLE from South America were not located when major data bases were examined. Consequently, this report describes the findings associated with NLE in a Brazilian 3.5-year-old female Yorkshire dog with neurological findings related to the myelencephalon; the dog died, besides medical treatment, and was submitted for autopsy exam and histopathological evaluation. Lesions were restricted to the encephalon and characterized as leukoencephalomalacia with severe non-suppurative inflammation with extensive perivascular cuffing; the non-suppurative inflammation was characterized by influx of lymphocytes and histiocytes, and occasionally plasma cells, and gitter cells. Infectious disease agents were not identified by molecular techniques or visualized with histochemical stains. This report represents the first definitive diagnose of NLE in Brazil, suggesting that this disease may be present in South America dogs suffering from neurological conditions. This knowledge may be useful for veterinarians in Brazil, taking into account that this disease should be considered as a differential diagnosis when infectious causes are excluded.

Key words: Necrotizing encephalitis. Dog. Neuropathology.
\end{abstract}

\section{Resumo}

Leucoencefalite necrosante (LEN) é uma condição inflamatória encefálica incomum. A NLE foi descrita em cães da América do Norte, Europa e Ásia, mas, de acordo com o conhecimento dos autores, não há diagnóstico definitivo dessa doença na América do Sul. O objetivo do presente relato foi descrever um caso de leucoencefalite necrosante diagnosticado em um cão do Brasil. A doença é descrita em um cão Yorkshire fêmea de 3,5 anos com apresentação neurológica afetando principalmente o mielencéfalo; o animal veio a óbito, apesar do tratamento médico, e foi submetida a autopsia e avaliação histopatológica. As lesões estavam restritas ao encéfalo e foram caracterizadas por necrose da substância branca e extensa inflamação não-supurativa do neurópilo e presença de grandes manguitos perivasculares; a resposta inflamatória não-supurativa foi caracterizada principalmente por infiltração de linfócitos e histiócitos, e ocasionais plasmócitos e células gitter. Agentes infecciosos não foram detectados por técnicas

1 Prof., Programa de Pós-Graduação em Biociência Animal, Setor de Clínica Médica de Pequenos Animais, Universidade de Cuiabá, UNIC, Cuiabá, MT, Brasil. Brasil. E-mail: amamude@hotmail.com

2 Prof $^{a}$ Dr $^{\mathrm{a}}$, Programa de Pós-Graduação em Ciência Animal, Universidade Estadual de Londrina, UEL, Departamento de Clínicas Veterinárias, Londrina, PR, Brasil. E-mail: vicky@uel.br

3 Profs. Drs., Programa de Pós-Graduação em Ciência Animal, UEL, Laboratório de Patologia Animal, Departamento de Medicina Veterinária Preventiva, Londrina, PR, Brasil. Brasil. E-mail: selwyn.headley@uel.br; anapaula@uel.br

4 Discente de Doutorado, Programa de Pós-Graduação em Biociência Animal, UNIC, Cuiabá, MT, Brasil. E-mail: natalino. biologo@hotmail.com

5 Prof. Dr., Programa de Pós-Graduação em Ciência Animal, UEL, Laboratório de Virologia Animal, Departamento de Medicina Veterinária Preventiva, Londrina, PR, Brasil. Brasil. E-mail: alfieri@uel.br

* Author for correspondence

Received: Mar. 22, 2019 - Approved: Aug. 04, 2019 
moleculares e também não foram identificados por colorações histológicas. Este relato representa o primeiro caso de LEN com diagnóstico anatomopatológico no Brasil, demonstrando que esta doença está presente em cães Sul Americanos que sofrem de condições neurológicas. Esta informação é útil para os médicos veterinários no Brasil, levando em consideração que esta doença deve ser considerada como um diagnóstico diferencial quando as causas infecciosas forem excluídas.

Palavras-chave: Encefalite necrosante. Cão. Neuropatologia.

\section{Introduction}

Necrotizing encephalitis (NE) is a unique nonsuppurative inflammatory disease of the brain that occurs in specific breeds of dogs, including the Pug, Maltese, and Yorkshire breeds; however, similar disease has been described in other breeds such as the Chihuahua, Pekingese, Papillon, French Bull dog, Shih Tzu, Coton de Tulear, and Brussels Griffon has been affected (COOPER et al., 2014).

Based on the distribution of the necrotizing lesions within the neuroparenchyma, two distinct syndromes have been recognized: necrotizing meningoencephalitis (NME) and necrotizing leukoencephalitis (NLE). In NME lesions affecting the cerebral gray matter is the main feature of the disease (PARK et al., 2014), while necrosis is restricted to the deep white matter of the cerebrum and/or brainstem in NLE (TIPOLD et al., 1993; LEZMI et al., 2007).

Although NLE has been described in dogs from North America (SCHATZBERG et al., 2005), Europe (TIPOLD et al., 1993; LEZMI et al., 2007), and Asia (KUWAMURA et al., 2002; JUNG et al., 2013; PARK et al., 2014), cases of this syndrome in South America dogs were not located when major databases were searched. This report describes the occurrence of NLE in a Yorkshire terrier dog from Brazil, thereby confirming the worldwide distribution of this unique syndrome.

\section{Case Report}

A 3.5-year-old, female, Yorkshire dog with a history of visual impairment and stumbling into objects was admitted at the Veterinary Teaching Hospital; systemic signs were not observed. A neurological evaluation revealed vestibular ataxia, circling, generalized tremor, decreased postural reactions, multiple cranial nerve deficits, and preserved spinal reflexes. Cranial nerve dysfunctions were characterized by right side deficits, which included depressed facial sensitivity with mild facial paralysis, depressed palpebral and corneal reflexes, and ventrolateral strabismus. Bilaterally positional vertical nystagmus and the absence of the oculocephalic reflex were also observed. These results suggested a neuroanatomical diagnosis of right side hindbrain (caudal brainstem) dysfunction. Cerebrospinal fluid (CSF) was collected and an inflammatory disease was suspected due to an increase in the protein concentration - $47 \mathrm{mg} / \mathrm{dl}$ (12 - $25 \mathrm{mg} / \mathrm{dl}$ - normal/physiological range) and lymphocytic pleocytosis - 30 cells/ $\mathrm{mm}^{3}(0-5$ cells $/ \mathrm{mm}^{3}$ - normal/physiological range). The dog was serologically negative for Toxoplasma gondii and Neospora caninum; while bacterial and fungal organisms were not observed in the CSF. A RT-PCR assay to amplify nucleic acids of canine distemper virus (CDV) from the CSF also yielded negative results. Initial medication with steroids resulted in adequate responses. However, three months after therapy, the neurological status of the dog deteriorated, and the owner requested euthanasia.

At autopsy, lesions were restricted to the nervous tissue (Figure 1), and other organs were not affected. The vessels of the meninges were mildly congested. On cut section of the fixed encephalon, foci of greyish discoloration, probably due to leukoencephalomalacia, were verified into the rhombencephalon, at the right caudal brainstem. Gross alterations spared the forebrain/ prosencephalon (telencephalon and diencephalon) mesencephalon (midbrains), as well as the the cerebellum - dorsal plane of the rombencephalus (hidbrain). The histopathological alterations were 
mainly in the ventral rhombencephalus (caudal brainstem) (Figure 1A) and consisted of necrosis and non-suppurative inflammation of the white matter. In areas of leukoencephalomalacia there was microcystic formations associated with severe influx of lymphocytes, histiocytes, and occasional plasma cells and Gitter cells (Figure 1B). This mixture inflammatory cells were adjacent to or surrounding these necrotic areas. In addition, there were multifocal to coalescing perivascular cuffings formed by these inflammatory cells (Figure 1C and 1D), astrocytosis, astrogliosis, with severe proliferation of gemistocytic astrocytes, vascular proliferation, and intense microglial cell proliferation. Occasional scattered small perivascular cuffs were randomly distributed within the white matter of the forebrain without other neuroparenchymal changes at this neuroanatomical site. Mesencephalon and cerebellum were not affected. Infectious organisms were not identified with the histochemical stains [Gram, Periodic Acid-Schiff, and Grocott's methenamine silver]. Moreover, antigens of CDV were not identified by immunohistochemical assay (Serotec, Kidlington, Oxford, UK; dilution of the CDV anti-antibodies at 1/500); RT-PCR assay did not amplify for CDV mRNA in fresh fragments of the brain, and a PCR assay did not identify amplify canine herpesvirus-1 form selected formalin-fixed paraffin-embedded tissue sections of the encephalon.

Figure 1. Histological sections from a Yorkshire dog with necrotizing leukoencephalitis. A -Right myelencephalon showing the typical anatomic location of NLE-associated lesions. H\&E stain, sub macroscopic view. B - Microcystic malacia (asterisk) with inflammatory cells influx near of the necrosis, mainly around the vessels forming extensive perivascular cuffing (arrows). H\&E stain, obj. 10x. C - Non-suppurative inflammatory infiltrate around the vessel perivascular cuffing (asterisk); the inflammatory cells also invaded the neuropil (arrows) though Virchow Robin space (head arrows). H\&E stain, obj. 40x. D - Non-suppurative inflammatory infiltrate he observed mainly lymphocytes (arrows) and histiocytes (head arrows). H\&E stain, 100x.

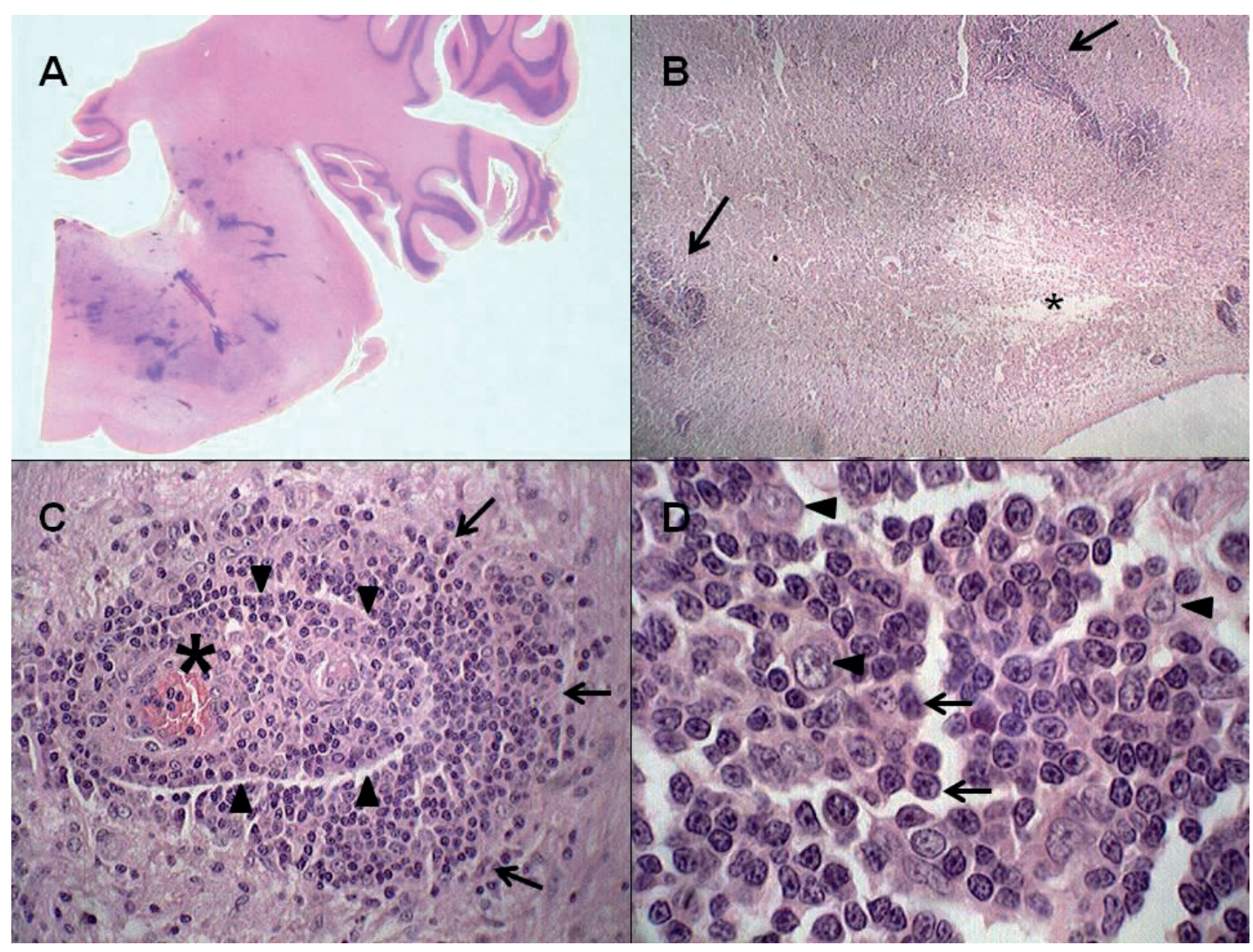

Semina: Ciências Agrárias, Londrina, v. 40, n. 6, suplemento 2, p. 3321-3326, 2019 


\section{Discussion}

A diagnosis of NLE was established due to the absence of infectious organisms within the brain and the nature and distribution of the lesions; necrosis restricted to the deep white matter of the cerebrum is the major feature of NLE (TIPOLD et al., 1993; KUWAMURA et al., 2002; LEZMI et al., 2007). Although the brainstem may not be the most affected neuroanatomical location in most of dogs with NLE, some cases have been presented mainly with severe hindbrain lesions and minor cerebral involvement (TIPOLD et al., 1993), such as verified in the presented case.

NLE and NME have been described in prototypical breeds, since particular breeds have been reported with histopathologic lesions more characteristic of one type of NE. Accordingly, Pugs, Maltese and Chihuahuas have been the prototypical "NME breeds", while Yorkshire Terrier, classically has been described as the traditional "NLE breed" (TIPOLD et al., 1993; PARK et al., 2014). Alternatively, some reports (COOPER et al., 2014) have verified overlap in the variables by which NME and NLE are characterized. The variable degree of necrosis and lesion topography between NME and NLE might reflect minor genotypic differences within and among such breeds. For instance, Pugs and Chihuahuas, the prototypical NME breeds, have been reported with neuropathologic lesions characteristic of NLE, whereas NME has been reported in a Yorkshire Terrier that has been the prototypical NLE breed (COOPER et al., 2014). In Brazil, Yorkshire dogs have been officially diagnosed with NE (VIOTT et al., 2007; HOSOMI et al., 2009); however, in these dogs from Brazil the clinicopathological features were compatible with what is known for NME rather than NLE, since necrosis and inflammation in such cases were pronounced at the cortical gray matter.

NLE has been diagnosed mainly in Yorkshire dogs (TIPOLD et al., 1993; KUWAMURA et al.,
2002; SCHATZBERG et al., 2005; VON PRAUN et al., 2006; LEZMI et al., 2007; BEARD et al., 2011; PARK et al., 2014). Additionally, NLE was also observed in one Chihuahua and two French bulldogs (COOPER et al., 2014), and in the Shih $\mathrm{Tzu}$ and a Maltese breed of dogs (JUNG et al., 2013; KIM et al., 2014). Although there are 25 cases reported with NLE, the worldwide actual incidence of the disease is surely underestimated; the disease is well known in Europe and USA from over 20 years. However, the diagnosis of NLE in a new geographical location where the disease was not previously registered may contribute to the knowledge of the NE epidemiology. NLE has been diagnosed in Asia, North America, Europe and Oceania (TIPOLD et al., 1993; KUWAMURA et al., 2002; SCHATZBERG et al., 2005; VON PRAUN et al., 2006; LEZMI et al., 2007; BEARD et al., 2011; JUNG et al., 2013; KIM et al., 2014; PARK et al., 2014); nevertheless, there is no report of this disease in South America. Consequently, the importance of this study lies in the characterization of NLE in a Yorkshire dog from Brazil, suggesting that the distribution of this neurological syndrome is worldwide.

\section{Conclusion}

This report suggests that this disease may be present among Brazilian dogs suffering from neurological conditions. This information may be useful to clinicians and pathologists in Brazil; this disease should be considerate as a differential diagnosis of encephalitis when infectious causes have been excluded.

\section{References}

BEARD, P. M.; MUNRO, E.; GOW, A. C. A quadrigeminal dermoid cyst with concurrent necrotizing granulomatous leukoencephalomyelitis in a Yorkshire Terrier dog. Journal of Veterinary Diagnostic Investigation, Thousand Oaks, v. 23, n. 5, p. 1075-1078, 2011. DOI: $10.1177 / 1040638711416630$ 
COOPER, J. J.; SCHATZBERG, S. J.; VERNAU, K. M.; SUMMERS, B. A.; PORTER, B. F.; SISO, S.; YOUNG, B. D.; LEVINE, J. M. Necrotizing meningoencephalitis in atypical dog breeds: a case series and literature review. Journal of Veterinary Internal Medicine, Malden, v. 28, n. 1, p. 198-203, 2014. DOI: 10.1111/jvim. 12233

HOSOMI, F. Y. M.; RAMOS, A. T.; MASUDA, E. K.; TROST,M.E.; GRAÇA, D.L.; MAIORKA,P.C.Aspectos clínico-patológicos em casos de meningoencefalite necrosante canina. Clínica Veterinária, São Paulo, v. 14, n. 81, p. $62-68,2009$.

JUNG, D. I.; LEE, H. C.; HA, J.; JUNG, H. W.; JEON, J. H.; MOON, J. H.; LEE, J. H.; KIM, N. H.; SUR, J. H.; KANG, B. T.; CHO, K. W. Unsuccessful cyclosporine plus prednisolone therapy for autoimmune meningoencephalitis in three dogs. The Journal of Veterinary Medical Science, Tokyo, v. 75, n. 12, p. 16611665, 2013. DOI: 10.1292/jvms.12-0503

KIM, B.; YI, K.; JUNG, S.; JI, S.; CHOI, M.; YOON, J. Clinical applications and characteristics of apparent diffusion coefficient maps for the brain of two dogs. Journal of Veterinary Science, Seoul, v. 15, n. 3, p. 455458, 2014. DOI: 10.4142/jvs.2014.15.3.455

KUWAMURA, M.; ADACHI, T.; YAMATE, J.; KOTANI, T.; OHASHI, F.; SUMMERS, B. A. Necrotizing encephalitis in the Yorkshire terrier: a case report and literature review. The Journal of Small Animal Practice, Oxford, v. 43, n. 10, p. 459-463, 2002. DOI: 10.1111/j.1748-5827.2002.tb00014.x

LEZMI, S.; TOUSSAINT, Y.; PRATA, D.; LEJEUNE, T.; FERREIRA-NEVES, P.; RAKOTOVAO, F.; FONTAINE, J. J.; MARCHAL, T.; CORDONNIER, N. Severe necrotizing encephalitis in a Yorkshire terrier: topographic and immunohistochemical study. The Journal of Veterinary Medical Science, Tokyo, v. 54, n. 4, p. 186190, 2007. DOI: 10.1111/j.1439-0442.2007.00925.x

PARK, E. S.; UCHIDA, K.; NAKAYAMA, H. Comprehensive immunohistochemical studies on canine necrotizing meningoencephalitis (NME), necrotizing leukoencephalitis (NLE), and granulomatous meningoencephalitis (GME). Veterinary Pathology, Thousand Oaks, v. 49, n. 4, p. 682-693, 2014. DOI: $10.1177 / 0300985811429311$

SCHATZBERG, S. J.; HALEY, N. J.; BARR, S. C.; DE LAHUNTA, A.; SHARP, N. J. Polymerase chain reaction screening for DNA viruses in paraffin-embedded brains from dogs with necrotizing meningoencephalitis, necrotizing leukoencephalitis, and granulomatous meningoencephalitis. Journal of Veterinary Internal Medicine, Malden, v. 19, n. 4, p. 553-559, 2005. DOI: 10.1111/j.1939-1676.2005.tb02726.x

TIPOLD, A.; FATZER, R.; JAGGY, A.; ZURBRIGGEN, A.; VANDEVELDE, M. Necrotizing encephalitis in Yorkshire terriers. The Journal of Small Animal Practice, Oxford, v. 34, n. 12, p. 623-628, 1993. DOI: 10.1111/ j.1748-5827.1993.tb02598.x

VIOTT, A. M.; AEODATO, A.; RAMOS, A. T.; MASUDA, E. K.; MARTINS, T. B.; GRAÇA, D. L. Meningoencefalite necrosante dos Yorkshires. Relato de caso. MEDVEP, Curitiba, v. 5, n. 16, p. 216-220, 2007.

VON PRAUN, F.; MATIASEK, K.; GREVEL, V.; ALEF, M.; FLEGEL, T. Magnetic resonance imaging and pathologic findings associated with necrotizing encephalitis in two Yorkshire terriers. Veterinary Radiology and Ultrasound, Oxford, v. 47, n. 3, p. 260264, 2006. DOI: 10.1111/j.1740-8261.2006.00137.x 
